\title{
Ventricular-Peritoneal Shunt in Newborns in a High-Risk Maternity Unit: Case Series
}

\section{Derivação ventrículo-peritoneal em recém-nascidos numa maternidade de alto risco: Série de casos}

\author{
Amanda Ferreira Barbosa ${ }^{1}$ José Nolasco de Carvalho Neto ${ }^{2}$ Carlos Alberto Miranda Lyra ${ }^{3}$ \\ Tiago de Paiva Cavalcante ${ }^{4}$ Rilton Marcus Morais ${ }^{5}$ Arthur Maynart Pereira Oliveira ${ }^{5}$ \\ ${ }^{1}$ Department of Medicine, Universidade Federal de Sergipe, Lagarto, \\ SE, Brazil \\ Address for correspondence Amanda Ferreira Barbosa, Rua Capitão \\ 2 Department \\ Isaias Alves de Souza, 1195, São Conrado, 49043-240, Aracaju, SE, \\ SE, Brazil \\ 3 Department of Medicine, Universidade Tiradentes, Aracaju, SE, Brazil \\ ${ }^{4}$ Department of Neurosurgery, Maternidade Nossa Senhora de \\ Lourdes, Aracaju, SE, Brazil \\ ${ }^{5}$ Department of Neurosurgery, Hospital de Cirurgia, Aracaju, SE, Brazil \\ Brazil (e-mail: amandabarbosaufs@outlook.com).
}

Arq Bras Neurocir 2020;39(2):79-82.

\begin{abstract}
Keywords

- ventricular-peritoneal shunt

- neurosurgery

- pediatrics
\end{abstract}

Objective To identify factors related to ventricular-peritoneal shunt (VPS) complications in pediatric patients at a high-risk maternity hospital.

Methods Prospective study, conducted between September/2018 and June/2019, with selected newborns without previous ventricular bypass who underwent neurosurgery for VPS placement in a high-risk maternity hospital in the state of Sergipe, Brazil. Diagnosis of hydrocephalus occurred by transfontanelle ultrasound. The variables were analyzed by Student $t$-test, adopting $p<0.05$ as statistical significance.

Results Seven newborns participated in the study, 3 male and 4 female. Folic acid supplementation during pregnancy was considered a positive influencing factor in the $1^{\text {st }}$ minute Apgar. Hydrocephalus secondary to premature hemorrhage was present in most newborns. Prematurity, $1^{\text {st }}$ minute Apgar score $<7$, and birth weight $<2,500 \mathrm{~g}$ did not represent a significant negative risk factor for prolonged hospitalization after neurosurgery. One newborn had cerebrospinal fluid infection and was the only one with heart disease. Conclusion This is the first scientific research that associates the benefits of maternal use of folic acid during pregnancy to better newborn Apgar scores. Only one newborn developed complications after neurosurgery, the only one with an associated comorbidity. Further studies are needed to provide more evidence on risk factors related to complications of VPS implantation in newborns. This neurosurgical procedure in a highrisk maternity contributed to the early management of hydrocephalus.

\section{Resumo}

Objetivo Conhecer fatores relacionados a complicações de derivação ventrículoperitoneal (DVP) em pacientes pediátricos numa maternidade de alto risco. received

November 2, 2019

accepted

January 15,2020
DOI https://doi.org/

10.1055/s-0040-1708891. ISSN 0103-5355.
Copyright $(2020$ by Thieme Revinter

Publicações Ltda, Rio de Janeiro, Brazil
License terms

(c) (1) $\ominus$ (\$) 


\begin{abstract}
Métodos Estudo prospectivo, realizado entre setembro/2018 e junho/2019, com seleção de recém-nascidos (RNs) sem derivação-ventricular prévia submetidos à neurocirurgia para colocação de DVP numa maternidade de alto risco no etsado do Sergipe, Brasil. O diagnóstico de hidrocefalia ocorreu pela ultrassonografia transfontanela. As variáveis foram analisadas pelo teste $T$ de Sudent, adotando $p<0,05$ como significância estatística.

Resultados Participaram do estudo sete RNs, sendo três do sexo masculino e quatro do sexo feminino. A suplementação de ácido fólico durante a gravidez foi considerada um fator de influência positivo no Apgar de $1^{\circ}$ minuto. Hidrocefalia secundária à hemorragia da prematuridade esteve presente na maioria dos RNs. Prematuridade, Apgar de $1^{\circ}$ minuto $<7$ e peso ao nascer $<2.500 \mathrm{~g}$ não representaram fator de risco negativo significativo para hospitalização prolongada após a neurocirurgia. Um RN apresentou infecção liquórica, sendo o único com cardiopatia.

Conclusão Esta é a primeira pesquisa científica que associa os benefícios da suple-

Palavras-chave

- derivação ventrículoperitoneal

- neurocirurgia

- pediatria mentação materna com ácido fólico durante a gravidez a melhores valores de Apgar do recém-nascido. Apenas um recém-nascido desenvolveu complicações após a neurocirurgia, o único com uma comorbidade associada. Mais estudos são necessários para fornecer mais evidências sobre os fatores de risco relacionados às complicações do implante de DVP em recém-nascidos. Esse procedimento neurocirúrgico em RNs numa maternidade de alto risco contribuiu com o manejo precoce da hidrocefalia.
\end{abstract}

\section{Introduction}

Postneurosurgical complications for ventricular-peritoneal shunt (VPS) placement are frequent, especially in the pediatric population during the neonatal period. ${ }^{1}$ It is fundamental to know the time of placement of shunt and the clinical manifestations suggestive of potential complications, since these factors can help in an earlier and efficient management of patients. $^{2}$

The negative aspects of the VPS system are complications, especially those of a mechanical nature, with valve malfunction representing the majority of cases. ${ }^{1,3}$ Thus, the most common complications of VPS are obstruction, followed by infection and catheter migration. 3,4

The pediatric population undergoing VPS has more frequent complications than adults. ${ }^{1}$ However, there are still few studies on the complications related to the immediate postoperative period of VPS in newborns, especially those born in high-risk gestational maternity referrals.

The present study aims to identify the factors related to the occurrence of complications associated with postoperative neurosurgery for placement of VPS in pediatric patients at the only public maternity specialized in high-risk gestation in the state of Sergipe, Brazil.

\section{Methods}

We prospectively selected, between September/2018 and June/2019, newborns submitted to neurosurgery for placement of VPS at the only public maternity unit specialized in high-risk gestation in the state of Sergipe, Brazil. The exclusion criteria of the study included previous neurosurgery procedure for the placement of ventricular shunts and/or non- signing of the informed consent form by the patient's supervisors.

We analyzed factors related to the parents (age and previous history of other children requiring ventricular diversion), prenatal (use of folic acid, gestational intercurrences and maternal comorbidities), route of birth (route of birth and postpartum procedures), neurosurgery (time of surgery, place of incision for VPS implantation, and intraoperative complications) and postoperative (complications related to VPS, length of hospital stay, and cephalic perimeter). These factors were associated with neurosurgery-related complications for VPS placement.

The study uses the concept of adequate prenatal care adopted by the Ministry of Health, Brazil. ${ }^{5}$ The diagnosis of hydrocephalus was made by transfontanelle ultrasonography, and a ventricular-cranial index above 0.15 was adopted as an abnormality. ${ }^{6}$

Data were systematized, analyzed, and described by absolute, relative and arithmetic mean frequencies. The variables were analyzed by the Student $t$-test, adopting $p<0.05$ as statistical significance. The research complies with all required ethical principles and is approved by the Research Ethics Committee of the Universidade Federal do Sergipe, under protocol 2.976.561.

\section{Results}

In the period seven patients were included in the study, all of them electively operated for VPS placement. The indication of neurosurgery for placement of VPS in newborns that were part of the study was hydrocephalus, confirmed by transfontanelle ultrasonography. All neurosurgeries were performed by pediatric neurosurgeons, the valves used were 
medium pressure and had the same model and manufacturer.

All mothers had single pregnancies, cesarean births, were multiparous, and had no other children who required neurosurgery for VPS. The average maternal age was 27 years. Only one (14.28\%) mother had a previous history of abortion. Most pregnant women ( $n=5 ; 71.42 \%)$ had adequate prenatal care.

Of the gestational complications and incidence of maternal prenatal diseases, the most frequent was urinary tract infection, which was present in more than half of the pregnant women $(n=04 ; 57.14 \%)$. In the prenatal period, no pregnant woman used alcohol or other drugs and did not present serological alterations for syphilis, rubella, toxoplasmosis, hepatitis, HIV, and cytomegalovirus.

Of the newborns who participated in the study, 03 (42.85\%) were male and 04 (57.14\%) were female, as shown in -Table 1. Newborns of pregnant women who did not receive folic acid supplementation during pregnancy $(n=03 ; 42.85 \%)$ presented $1^{\text {st }}$ minute Apgar $<7$. Folic acid supplementation during pregnancy was considered a positive influence factor in the $1^{\text {st }}$ minute Apgar, showing statistical significance with $p=0.04(p<0.05)$. Newborns of pregnant women using folic acid had an average $1^{\text {st }}$ minute Apgar score of 8.0, and a lack of folic acid resulted in newborns with an average score of 4.3 .

Of the newborns, 4 (57.14\%) had a gestational age $<37$ weeks. Hemorrhage due to prematurity was the main etiology of hydrocephalus, and it was present in 3 preterm infants. Only one premature newborn had the etiology of hydrocephalus as hydranencephaly. Results are shown in - Table 2.

The average age at which newborns underwent neurosurgery was 6.5 weeks of life (minimum 0 and maximum 14 weeks). The average time of neurosurgery was $1 \mathrm{~h}$ and $30 \mathrm{~min}$ (maximum $2 \mathrm{~h}$ and minimum $50 \mathrm{~min}$ ). Most incisions for distal and proximal fixation of the VPS catheter occurred in the transumbilical $(n=05 ; 71.42 \%)$ and parietal $(n=05$; $71.42 \%$ ) regions, respectively.

Although the incidence of hydrocephalus requiring VPS neurosurgery was higher in male newborns, the postneurosurgical hospitalization time was higher in female new-

Table 1 Characteristics of newborns who underwent ventricularperitoneal shunt neurosurgery

\begin{tabular}{|l|l|l|l|}
\hline \multicolumn{2}{|l|}{ Variables } & $\mathbf{n}$ & $\%$ \\
\hline \multirow{3}{*}{ Gender } & Female & 3 & 42.85 \\
\cline { 2 - 4 } & Male & 4 & 57.14 \\
\hline \multirow{3}{*}{ Gestational age } & $<31$ weeks & 2 & 28.57 \\
\cline { 2 - 4 } & $31-36$ weeks & 2 & 28.57 \\
\cline { 2 - 4 } & $37-42$ weeks & 3 & 42.85 \\
\hline \multirow{3}{*}{ Weight } & $<2,500 \mathrm{~g}$ & 4 & 57.14 \\
\cline { 2 - 4 } & $>2,500 \mathrm{~g}$ & 3 & 42.85 \\
\hline First minute Apgar & $<7$ & 4 & 57.14 \\
\cline { 2 - 4 } & $>7$ & 3 & 42.85 \\
\hline
\end{tabular}

Table 2 Etiology of hydrocephalus of newborns who underwent ventricular-peritoneal shunt neurosurgery

\begin{tabular}{|l|l|l|l|}
\hline $\begin{array}{l}\text { Etiology of } \\
\text { hydrocephalus }\end{array}$ & $\begin{array}{l}\text { Gestational } \\
\text { age (week) }\end{array}$ & $\mathbf{n}$ & \% \\
\hline Hydranencephaly & $>37$ & 1 & 28.57 \\
\cline { 2 - 3 } & $<37$ & 1 & 28.57 \\
\hline Myelomeningocele & $>37$ & 2 & 42.85 \\
\hline $\begin{array}{l}\text { Prematurity } \\
\text { hemorrhage }\end{array}$ & $<37$ & 3 & \\
\hline
\end{tabular}

borns, with the average number of days of hospitalization being 7.5 among boys and of 9.6 among girls. However, gender was not considered a risk factor for longer postoperative hospital stay, with $p=0.5(p>0.05)$.

In addition, it was associated with gestational age, newborn weight, Apgar in the 1st minute and use of folic acid in pregnancy on the days of hospital stay after neurosurgery for placing VPS, as shown in table 03. Although newborns younger than 37 weeks, with a 1 st minute Apgar score $<7$ and weighing $<2,500 \mathrm{~g}$ have a higher average of postoperative hospitalization, these factors do not represent a significant negative risk factor for hospitalization after the neurosurgery.

All newborns who underwent VPS also underwent postoperative antibiotic prophylaxis, with intravenous cephalothin $(1 \mathrm{~g} / 10 \mathrm{ml}$ ) being the antibiotic used, according to maternity standardization, from the first postoperative day. The duration of cephalothin use was an average of 5.14 days (minimum of 3 and maximum of 6 days). In addition, prophylaxis against intraoperative infections was performed in all neurosurgeries by vancomycin irrigation of the VPS catheter.

The mean time of postoperative observation until hospital discharge was 8.4 days (minimum of 4 and maximum of 14 days). During the postoperative observation, only 1 newborn (14.28\%) presented complication related to neurosurgery for placement of VPS. This newborn was female, the only one with intraoperative intercurrent events and congenital heart disease (the other newborns had no associated comorbidities).

Table 3 Factors related to the number of days of hospitalization after neurosurgery for ventricular-peritoneal shunt

\begin{tabular}{|c|c|c|c|c|}
\hline \multicolumn{2}{|l|}{ Variables } & \multirow{2}{*}{$\begin{array}{l}n \\
4\end{array}$} & \multirow{2}{*}{$\begin{array}{l}\text { Average days of } \\
\text { postoperative } \\
\text { hospitalization } \\
8.25\end{array}$} & \multirow{2}{*}{$\begin{array}{l}p \text {-value } \\
\\
0.9\end{array}$} \\
\hline \multirow{2}{*}{$\begin{array}{l}\text { Gestational } \\
\text { age (weeks) }\end{array}$} & $<37$ & & & \\
\hline & $>37$ & 3 & 8.66 & \\
\hline \multirow{2}{*}{$\begin{array}{l}\text { Birth weight } \\
\text { (grams) }\end{array}$} & $<2,500$ & 4 & 8.25 & \multirow[t]{2}{*}{0.9} \\
\hline & $>2,500$ & 3 & 8.66 & \\
\hline \multirow{2}{*}{$\begin{array}{l}1^{\circ} \text { minute } \\
\text { Apgar }\end{array}$} & $<7$ & 4 & 10 & \multirow[t]{2}{*}{0.2} \\
\hline & $>7$ & 3 & 6.3 & \\
\hline \multirow{2}{*}{$\begin{array}{l}\text { Folic acid in } \\
\text { pregnancy }\end{array}$} & Used & 4 & 7 & \multirow[t]{2}{*}{0.3} \\
\hline & $\begin{array}{l}\text { Did } \\
\text { not use }\end{array}$ & 3 & 10.3 & \\
\hline
\end{tabular}

${ }^{*} p<0.05$ is considered statistical significance. 
The complication developed was cerebrospinal fluid infection, and the procedure adopted was the removal of the VPS.

\section{Discussion}

Congenital or acquired childhood hydrocephalus represents a major medical and social problem, and some studies attribute an incidence of 1 to 3 per 1,000 births only for congenital or early onset hydrocephalus, to which are added the acquired hydrocephalus. ${ }^{7}$ Other studies indicate that the congenital form occurs from 3 to 4 per 1,000 live births. ${ }^{8}$ However, not all patients with hydrocephalus will place a ventricular shunt, and there is no consensus in the literature about the rate of hydrocephalus patients submitted to neurosurgery for VPS implantation. ${ }^{9}$

Most of the patients with hydrocephalus undergoing VPS neurosurgery were boys, and other published studies show a higher prevalence of hydrocephalus in boys. ${ }^{2,10}$

Folic acid supplementation showed no influence on the occurrence of hydrocephalus, but studies indicated that folic acid supplementation during pregnancy reduces the incidence of neural tube defects. ${ }^{11}$ In the research, babies born to mothers who did not supplement with folic acid during pregnancy had a $1^{\text {st }}$ minute Apgar score $<7$. This is the first scientific research that associates the benefits of folic acid supplementation during pregnancy to better newborn Apgar score values. Newborns of pregnant women using folic acid had an average $1^{\text {st }}$ minute Apgar score of 8.0, and a lack of folic acid resulted in newborns with an average score of 4.3.

In the current study, hemorrhage due to prematurity was the cause of hydrocephalus in most preterm infants. Preterm neonates, especially those with $<32$ weeks of gestation, and birth weight $<1,500 \mathrm{~g}$, and very low birth weight infants are more likely to develop intracranial hemorrhage, mainly from the germinative matrix, soon after birth or on the $1^{\text {st }}$ day after birth. $^{8}$

There was no relationship between postneurosurgical complications for VPS implantation and Apgar scores, birth weight, or gestational age, but some studies show that low weight and prematurity are associated with increased incidence of hydrocephalus. ${ }^{8-10}$ Although the incidence of hydrocephalus requiring VPS is higher in newborn boys, the average length of hospitalization after neurosurgery was higher among newborn girls.

In all neurosurgeries performed in the present study, the VPS catheter was flushed with vancomycin, and antibiotic impregnation of the catheters may have been associated with a reduction in infectious complications. ${ }^{1}$

\section{Conclusion}

Although the incidence of hydrocephalus requiring VPS is higher in newborn boys, the average length of hospitalization after neurosurgery was higher among newborn girls. Gestational $<37$ weeks, $1^{\text {st }}$ minute Apgar score $<7$, and birth weight $<2,500 \mathrm{~g}$ did not represent a significant negative risk factor for longer hospital stay after neurosurgery.

This is the first scientific research that associates the benefits of maternal supplementation with folic acid during pregnancy to the better newborn Apgar score values. Folic acid supplementation during pregnancy was considered a positive influence factor in the $1^{\text {st }}$ minute Apgar score, showing statistical significance with $p=0.04(p<0.05)$.

Only one newborn developed complications after neurosurgery, the only one with an associated comorbidity. However, further studies are needed to expand the sample size and provide additional evidence on the risk factors related to complications of VPS implantation in newborns.

This neurosurgical procedure in a high-risk maternity hospital contributed to the early treatment of hydrocephalus, with patients undergoing VPS before the $4^{\text {th }}$ month of life.

\section{Conflict of Interests}

The authors have no conflict of interests to declare.

\section{References}

1 Paff M, Alexandru-Abrams D, Muhonen M, Loudon W. Ventriculoperitoneal shunt complications: A review. Interdiscip Neurosurg 2018;13(01):66-70

2 Brouwer AJ, Groenendaal F, Koopman C, Nievelstein RJ, Han SK, de Vries LS. Intracranial hemorrhage in full-term newborns: a hospital-based cohort study. Neuroradiology 2010;52(06): 567-576

3 Mwachaka PM, Obonyo NG, Mutiso BK, Ranketi S, Mwang'ombe N. Ventriculoperitoneal shunt complications: a three-year retrospective study in a Kenyan national teaching and referral hospital. Pediatr Neurosurg 2010;46(01):1-5

4 Jucá CEB, Neto AL, de Oliveira SR, Machado HR. Treatment of hydrocephalus by ventriculoperitoneal shunt: analysis of 150 consecutive cases in the hospital of the faculty of medicine of Ribeirão Preto. Acta Cir Bras 2002;17(03):59-63

5 Secretaria de Atenção à Saúde. Gestação de alto risco: manual técnico. Brasília: Editora do Ministério da Saúde; 2008

6 Kirazli Y, Akkoc Y, Kanyilmaz S. Spinal epidural hematoma associated with oral anticoagulation therapy. Am J Phys Med Rehabil 2004;83(03):220-223

7 Kliemann SE, Rosemberg S. Hidrocefalia derivada na infância: um estudo clínico-epidemiológico de 243 observações consecutivas. Arq Neuropsiquiatr 2005;63(2B):494-501

8 da Cunha AHGB. Hidrocefalia na Infância. Rev Brasil Neurol Psiquiatr 2014;18(02):85-93

9 Martins FJ, Beserra NC, Barbosa LG. Perfil clínico e epidemiológico de crianças internadas por hidrocefalia num hospital municipal de São Paulo no periodo de 2014 a 2016. Rev Bras Neurol 2018;54 (01):25-31

10 Fachin MEL, Silva AC, Coelho FRD, Ribeiro MNS. Perfil epidemiológico de crianças com hidrocefalia atendidos no. Hosp Públ Manaus 2013;19(01):137-139

11 Bizzi JWJ, Machado A. Mielomeningocele: conceitos básicos e avanços recentes. J Brasil Neurocirur 2012;23(02):138-151 